\title{
KUALITAS PELAYANAN PEMUNGUTAN PAJAK KENDARAAN BERMOTOR PADA KANTOR BERSAMA SAMSAT KOTA BATAM
}

\author{
Razaki Persada \\ Universitas Internasional Batam \\ Persadarazaki@yahoo.com
}

\begin{abstract}
ABSTRAK. Fenomena yang dijadikan obyek penelitian adalah kualitas pelayanan pemungutan pajak kendaraan bermotor pada Kantor Bersama Samsat Kota Batam. Tujuan penelitian adalah membahas kualitas pelayanan serta memperoleh konsep baru tentang peningkatan kualitas pelayanan public. Penelitian yang digunakan adalah penelitian kualitatif. Penentuan informan penelitian sebanyak 10 orang menggunakan metode purposive sampling. Pengumpulan data menggunakan studi kepustakaan, teknik wawancara, dan observasi. Pengolahan data menggunakan metode analisis deskriptif dengan pendekatan analisis triangulasi. Dari pembahasan hasil penelitian diperoleh kesimpulan sebagai berikut : Faktor tangible yang meliputi penyediaan loket-loket, ruang tunggu, dan petugas pelayanan cukup memadai. Faktor responsiveness yang meliputi respon petugas pelayanan pada keluhan, kritikan dan kesulitan penerima layanan kurang baik karena itu belum memenuhi harapan para penerima layanan. Respon petugas pelayanan pada kesulitan penerima layanan dianggap kurang Faktor assurance yang meliputi kemampuan petugas, kelancaran teknis dan ketepatan waktu pelayanan cukup baik. Faktor emphaty yang meliputi kesiapan petugas, perhatian petugas dan kepedulian petugas pelayanan cukup baik. Faktor reliability yang meliputi keandalan individu petugas, keandalan unit-unit pelayanan, dan keandalan organisasi Kantor Bersama Samsat Kota Batan cukup baik. Temuan empirik yang dkembangkan menjadi konsep baru adalah tentang respon petugas pelayanan untuk meningkatkan kualitas pelayanan publik yang meliputi respon petugas pelayanan pada keluhan penerima layanan, respon petugas pelayanan pada kritikan penerima layanan dan respon petugas pelayanan pada kesulitan penerima layanan.
\end{abstract}

Kata kunci: Tangible; Responsiveness; Reability; Empathy.

\section{QUALITY SERVICES OF VEHICLES TAX AT ONE ROOF ADMINISTRATIVE SYSTEM (SAMSAT) IN BATAM}

ABSTRACT. The phenomenon that made the object of research is the serve quality of vehicle tax collections in Batam SAMSAT Office. The purpose of this research is to address service quality and gain a new concept of improving the quality of public service. Research is qualitative research. Determination of study informants were 10 used purposive sampling method. Collecting data using literature study, interview techniques, and observation. Processing data using 
descriptive analysis. From the forgoing results were obtained with the following conclusion: Tangible factors which include the provision of counter, waiting room, and officers with adequate services. Responsiveness factor that included service officer response to complaints, criticisms and difficulties receiving services is less good because it has not met the expectations of the recipient. Response to the difficulty in receiving care workers are considered less service assurance factors which include the ability of officers, technical fluency and timelines of service is quite good. Empathy factors which include personnel readiness, attention and care worker is quite good. Reliability factors, including the reliability of individual officers, reliability of service units, and reliability organization of Kantor Samsat Batam good enough. Empirical finding, developed a new concept is about the response of frontline employees to improve the quality of public service, including care workers in response to complaints the service recipient, the response of frontline employees in accepting criticism and response service care workers in difficulty receiving services.

Keywords: Tangible; Responsiveness; Reability; Empathy.

\section{PENDAHULUAN}

Guna membiayai pelaksanaan berbagai kebijakan dan kegiatan pembangunan, kegiatan pelayanan publik dan kegiatan pemberdayaan masyarakat, pemerintah daerah membutuhkan dukungan anggaran yang maksimal. Tujuan pelaksanaan berbagai kebijakan dan kegiatan tersebut adalah mewujudkan kesejahteraan masyarakat. Tujuan inilah yang harus dicapai melalui pelaksanaan fungsi-fungsi pemerintahan seperti misalnya fungsi pembangunan, fungsi pelayanan publik dan fungsi pemberdayaan masyarakat. Pelaksanaan fungsi-fungsi pemerintahan tersebut jelas membutuhkan dukungan anggaran yang maksimal, agar pelaksanaan fungsi-fungsi pemerintahan oleh Satuan-satuan Kerja Perangkat Daerah (SKPD) dapat berlangsung efektif dalam menyikapi, mengatasi dan sekaligus mengantisipasi perkembangan, kebutuhan dan permasalahan masyarakat Kota Batam.

Untuk itu, Pemerintah Daerah Kota Batam perlu menggali berbagai sumber penerimaan negara agar diperoleh penerimaan daerah yang dapat memenuhi kebutuhan pembiayaan. Cakupan pembiayaan yang dimaksud tentu tidak terbatas hanya untuk kebutuhan anggaran di tingkat daerah namun mencakup pula kebutuhan anggaran di tingkat Kelurahan. Karena itu, kinerja pengelolaan sumbersumber penerimaan Pendapatan Asli Daerah (PAD) menjadi sangat penting dan bernilai strategis dalam menyelenggarakan kebijakan administrasi dan sistem manajemen pemerintahan daerah. Bahkan keberhasilan dalam mengelola sumbersumber penerimaan daerah sesuai dengan ketentuan yang berlaku merupakan salah satu indikator keberhasilan Pemda Kota Batam dalam melaksanakan kebijakan desentralisasi. 
Salah satu sumber penerimaan daerah yang cukup potensial untuk meningkatkan penerimaan Negara yang ditetapkan menjadi sumber penerimaan pendapatan Pemerintah Daerah Provinsi adalah penerimaan pajak dan retribusi. Cukup banyak sumber penerimaan Negara yang dikelola oleh Pemerintah Daerah Provinsi. Untuk Pemerintah Daerah Provinsi, Pasal 2 ayat (1) Undang-Undang Nomor 34 ahun 2000 tentang Perubahan Atas Undang-Undang Nomor 18 Tahun 1997 tentang Pajak Daerah dan Retribusi Daerah menyebutkan Pajak Kendaraan Bermotor dan Kendaraan di Atas Air; Bea Balik Nama Kendaraan Bermotor dan Kendaraan di Atas Air; Pajak Bahan Bakar Kendaraan Bermotor; dan Pajak Pengambilan dan Pamanfaatan Air Bawah Tanah dan Air Permukaan merupakan jenis-jenis pajak Provinsi.

Manfaat hasil pemungutan Pajak Kendaraan Bermotor (PKB) dan Bea Balik Nama Kendaraan Bermotor (BBN-KB) merupakan salah satu sumber penerimaan Pendapatan Daerah Provinsi Kepulauan Riau yang tidak hanya untuk memenuhi sebagian kebutuhan pembiayaan daerah provinsi namun sekaligus juga memenuhi sebagian kebutuhan pembiayaan daerah Kota Batam. Karena itu, seiring dengan semakin meningkatnya jumlah kepemilikan kendaraan bermotor di Provinsi Kepulauan Riau terutama peningkatan jumlah kepemilikan kendaraan bermotor di Kota Batam, maka upaya peningkatan penerimaan PKB dan BBN-KB perlu dilakukan, agar kontribusi kedua jenis penerimaan pajak tersebut semakin besar terhadap pemenuhan kebutuhan pembiayaan daerah. Dengan demikian ketergantungan daerah pada kebijakan keuangan pemerintah akan semakin berkurang, dan pada akhirnya akan menumbuhkan kemandirian daerah dalam melaksanakan kebijakan desentralisasi.

Mengacu pada realisasi penerimaan PKB dan penerimaan BBN-KB, pertanyaan yang layak mendapat jawaban adalah "Apakah pemungutan kedua jenis pajak tersebut sudah disertai dengan peningkatan kualitas pelayanan kepada para wajib pajak?' Pertanyaan seperti ini layak dijawab karena kualitas pelayanan yang diselenggarakan oleh Kantor Bersama Samsat Kota Batam masih belum optimal, bila dinilai dari beberapa indikator. Terhadap fenomena belum optimalnya kualitas pelayanan pemungutan Pajak Kendaraan Bermotor tersebut, pertanyaannya adalah "Bagaimana kualitas pelayanan pemungutan pajak kendaraan bermotor di Kantor Bersama Samsat Kota Batam?". Untuk menjawab pertanyaan tersebut dipilih judul penelitian "Kualitas Pelayanan Pemungutan Pajak Kendaraan Bermotor pada Kantor Bersama Samsat Kota Batam".

Penelitian dimaksudkan untuk membahas masalah-masalah yang terkait dengan pelayanan publik di bidang perpajakan. Penelitian juga dimaksudkan untuk mengungkap fenomena pelayanan publik yang diselenggarakan oleh unit kerja birokrasi pemerintahan di daerah. Dengan maksud tersebut maka tujuan penelitian adalah memperoleh suatu konsep baru tentang kualitas pelayanan publik di bidang perpajakan yang diharapkan dapat dijadikan kontribusi bagi pengembangan ilmu pengetahuan terutama Ilmu Pemerintahan. 


\section{METODE}

Untuk mengungkap dan membahas permasalahan kualitas pelayanan pemungutan pajak kendaraan bermotor oleh Kantor Samsat Kota Batam digunakan pendekatan penelitian kualitatif. Pendekatan penelitian ini dilaksanakan dengan metode analisis deskriptif. Data didapat langsung dari sejumlah nara sumber yang dijadikan informan penelitian. Jenis data ini berfungsi untuk mengungkap persepsi dan ekspektasi nara sumber sebagai wajib pajak yang langsung melihat, merasakan dan mengalami kinerja pelayanan yang diselenggarakan oleh Kantor Bersama Samsat Kota Batam. Pengungkapan dilakukan dengan mengembangkan pokok-pokok pertanyaan penelitian yang disusun berdasarkan acuan teori servequal dari Zeithaml et. al. Data sekunder didapat dari buku-buku dan berbagai dokumen resmi serta berbagai tulisan yang diperlukan dan atau memenuhi kebutuhan akan informasi untuk mengungkap dan membahas masalah yang dijadikan obyek penelitian.

Penentuan nara sumber yang dijadikan informan penelitian menggunakan metode purposive sampling. Informan penelitian sebanyak 10 orang. Jumlah dan unsur nara sumber yang menjadi informan penelitian terdiri atas 5 orang wajib pajak kendaraan bermotor roda empat umum, 3 orang wajib pajak kendaraan bermotor roda empat pribadi, dan 2 orang wajib pajak kendaraan bermotor roda dua. Untuk mengumpulkan data primer dan data sekunder digunakan teknik pengumpulan data yang terdiri atas Observasi, Studi Kepustakaan, dan Teknik Wawancara. Perencanaan wawancara dilakukan dengan menyusun Pedoman Wawancara yang berisi pokok-pokok pertanyaan terbuka. Pokok-pokok pertanyaan tersebut kemudian dikembangkan pada waktu dilakukan wawancara.

Agar data yang terkumpul dapat dipercaya maka dilakukan pemeriksaan data untuk mengetahui sejauhmana representasi data dapat mengungkap masalah yang dijadikan obyek penelitian. Pemeriksaan data dilakukan juga untuk membuat klasifikasi data untuk menentukan kinerja analisis data. Kinerja analisis data ini dilakukan dengan pendekatan triangulasi. Setelah rangkaian data terkumpul, selanjutnya dilakukan olah data dengan prosedur dan teknis pengolahan berikut : (1) Melakukan pemilahan dan penyusunan klasifikasi data; (2) Melakukan penyunting data dan pemberian kode data untuk membangun kinerja analisis data; (3) Melakukan konfirmasi data yang memerlukan verifikasi data dan pendalaman data; dan (4) Melakukan analisis data sesuai dengan konstruksi pembahasan hasil penelitian.

\section{HASIL PENELITIAN DAN PEMBAHASAN \\ Analisis Faktor Tangible}

Faktor tangible adalah sarana dan prasarana serta fasilitas teknis pelayanan yang langsung dapat dilihat, dirasakan dan atau dimanfaatkan oleh para penerima layanan ketika mengurus pembayaran pajak kendaraan bermotor di Kantor Bersama Samsat Kota Batam. Faktor tangible yang dimaksud meliputi penyediaan loket-loket pelayanan, ruang tunggu pelayanan dan petugas pelayanan. Dari 
diskusi masalah-masalah yang terkait dengan faktor tangible yang tampak dalam penyelenggaraan pelayanan pemungutan pajak kendaraan bermotor di Kantor Bersama Samsat Kota Batam, teridentifikasi kondisi pelayanan sebagai berikut :

Pertama, penyediaan loket-loket untuk memperoleh pelayanan administrasi balik nama kendaraan bermotor, memperoleh STNK dan melunasi pajak kendaraan bermotor cukup memadai. Namun jumlah loket tersebut menjadi kurang memadai ketika jumlah kehadiran para wajib pajak melebihi kapasitas penyediaan loket. Akibatnya, tampak antrian yang bisa menimbulkan keluhan di kalangan penerima layanan, yaitu para wajib pajak yang mengurus balik nama kendaraan bermotor, STNK dan melunasi pajak kendaraan bermotor. Meskipun terkesan sederhana, namun bila masalah antrian para wajib pajak di loket-loket pelayanan tidak segera diatasi, maka dapat dinyatakan bahwa persepsi para wajib pajak terhadap kinerja pelayanan tidak sesuai ekspetasinya. Artinya, kepuasan penerima layanan belum terpenuhi. Dengan pandangan lain, kualitas pelayanan publik yang diselenggarakan oleh Kantor Bersama Samsat Kota Batam menurut indikasi loket pelayanan masih belum optimal.

Kedua, penyediaan ruang tunggu untuk para wajib pajak yang mengurus balik nama kendaraan bermotor, memperoleh STNK dan melunasi pajak kendaraan bermotor cukup memadai. Namun ruang dan fasilitas ruang tunggu tersebut menjadi kurang memadai ketika jumlah kehadiran para wajib pajak melebihi kapasitas ruang tunggu tersebut. Akibatnya, suasana menunggu proses pelayanan bisa menimbulkan keluhan di kalangan penerima layanan, yaitu para wajib pajak yang mengurus balik nama kendaraan bermotor, STNK dan melunasi pajak kendaraan bermotor. Meskipun terkesan sederhana, namun bila keluhan para wajib pajak pada waktu menunggu proses pelayanan tidak segera diatasi, maka dapat dinyatakan bahwa persepsi para wajib pajak terhadap kinerja pelayanan tidak sesuai ekspetasinya. Artinya, kepuasan penerima layanan belum terpenuhi. Dengan pandangan lain, kualitas pelayanan publik yang diselenggarakan oleh Kantor Bersama Samsat Kota Batam menurut indikasi ruang tunggu masih belum optimal.

Ketiga, meskipun jumlah petugas pelayanan dianggap cukup memadai, namun kompetensi petugas pelayanan untuk memberikan layanan informasi urusan balik nama kendaraan bermotor, memperoleh STNK dan melunasi pajak kendaraan bermotor kurang memadai. Akibatnya, para wajib pajak yang membutuhkan informasi pelayanan tidak memperoleh layanan informasi yang dibutuhkannya. Meskipun terkesan sederhana, namun bila masalah pemberian informasi layanan tidak segera diatasi, maka dapat dinyatakan bahwa persepsi para wajib pajak terhadap kinerja pelayanan tidak sesuai ekspetasinya. Artinya, kepuasan penerima layanan belum terpenuhi. Dengan pandangan lain, kualitas pelayanan publik yang diselenggarakan oleh Kantor Bersama Samsat Kota Batam menurut indikasi petugas pelayanan masih belum optimal. 


\section{Analisis Faktor Resposiveness}

Respon atau tanggapan para petugas pelayanan terhadap kebutuhan dan atau keluhan para penerima layanan adalah faktor komunikasi sosial yang bernilai strategis dalam membangun mekanisme kinerja pelayanan publik yang optimal. Respon yang dimaksud meliputi respon petugas terhadap keluhanan penerima layanan, respon petugas terhadap kritikan penerima layanan, dan respon petugas terhadap kesulitan penerima layanan. Dari diskusi masalah-masalah yang terkait dengan faktor responsiveness yang tampak dari para petugas pelayanan pemungutan pajak kendaraan bermotor di Kantor Bersama Samsat Kota Batam, teridentifikasi kinerja aparatur pelayanan sebagai berikut :

Pertama, respon pada keluhan penerima layanan belum optimal, karena respon petugas pelayanan masih belum memenuhi harapan para penerima layanan yaitu para wajib pajak yang tengah mengurus keperluan administrasi balik nama kendaraan bermotor, STNK dan pembayaran pajak kendaraan bermotor. Belum optimalnya respon petugas pelayanan pada keluhan penerima layanan disebabkan lemahnya kemampuan sosial petugas pelayanan tersebut dalam berkomunikasi dan menyampaikan informasi pelayanan. Akibatnya, para penerima layanan, yaitu para wajib pajak yang mengurus balik nama kendaraan bermotor, STNK dan pembayaran pajak kendaraan bermotor merasa kurang puas terhadap kinerja pelayanan yang diselenggarakan oleh Kantor Bersama Samsat Kota Batam. Meskipun penyediaan prasarana dan fasilitas pelayanan dianggap memadai, namun bila masalah respon petugas pelayanan pada keluhan penerima layanan tidak segera diatasi, maka dapat dinyatakan bahwa persepsi para wajib pajak terhadap kinerja pelayanan yang diselenggarakan oleh Kantor Bersama Samsat Kota Batam tidak sesuai ekspetasi para wajib pajak. Artinya, kepuasan penerima layanan belum terpenuhi. Dengan pandangan lain, kualitas pelayanan publik yang diselenggarakan oleh Kantor Bersama Samsat Kota Batam menurut indikasi respon petugas pelayanan pada keluhan penerima layanan masih belum optimal.

Kedua, respon pada kritikan penerima layanan belum optimal, karena respon petugas pelayanan masih belum memenuhi harapan para penerima layanan yaitu para wajib pajak yang tengah mengurus keperluan administrasi balik nama kendaraan bermotor, STNK dan pembayaran pajak kendaraan bermotor. Belum optimalnya respon petugas pelayanan pada kritikan penerima layanan disebabkan petugas pelayanan belum terbiasanya menerima kritikan dan saran dari masyarakat penerima layanan. Akibatnya, para penerima layanan, yaitu para wajib pajak yang mengurus balik nama kendaraan bermotor, STNK dan pembayaran pajak kendaraan bermotor merasa kurang puas terhadap kinerja petugas pelayanan. Meskipun penyediaan prasarana dan fasilitas pelayanan dianggap memadai, namun bila masalah respon petugas pelayanan pada kritikan penerima layanan tidak segera diatasi, maka dapat dinyatakan bahwa persepsi para wajib pajak terhadap kinerja pelayanan yang diselenggarakan oleh Kantor Bersama Samsat Kota Batam tidak sesuai ekspetasi para wajib pajak. Artinya, kepuasan 
penerima layanan belum terpenuhi. Dengan pandangan lain, kualitas pelayanan publik yang diselenggarakan oleh Kantor Bersama Samsat Kota Batam menurut indikasi respon petugas pelayanan pada kritikan penerima layanan masih belum optimal.

Ketiga, respon pada kesulitan penerima layanan belum optimal, karena respon petugas pelayanan masih belum memenuhi harapan para penerima layanan yaitu para wajib pajak yang tengah mengurus keperluan administrasi balik nama kendaraan bermotor, STNK dan pembayaran pajak kendaraan bermotor. Belum optimalnya respon petugas pelayanan pada kesulitan penerima layanan disebabkan petugas pelayanan kurang memiliki kompetensi dan profesionalitas yang diperlukan untuk menyikapi kesulitan penerima layanan. Akibatnya, para penerima layanan, yaitu para wajib pajak yang mengurus balik nama kendaraan bermotor, STNK dan pembayaran pajak kendaraan bermotor merasa kurang puas terhadap kinerja petugas pelayanan. Meskipun penyediaan prasarana dan fasilitas pelayanan dianggap memadai, namun bila masalah respon petugas pelayanan pada kesulitan penerima layanan tidak segera diatasi, maka dapat dinyatakan bahwa persepsi para wajib pajak terhadap kinerja pelayanan yang diselenggarakan oleh Kantor Bersama Samsat Kota Batam tidak sesuai dengan ekspetasi para wajib pajak. Artinya, kepuasan penerima layanan belum terpenuhi. Dengan pandangan lain, kualitas pelayanan publik yang diselenggarakan oleh Kantor Bersama Samsat Kota Batam menurut indikasi respon petugas pelayanan pada kesulitan penerima layanan masih belum optimal.

\section{Analisis Faktor Assurance}

Assurance sebagai suatu cerminan kemampuan dan kesopanan petugas pelayanan dalam melaksanakan kegiatan pelayanan yang dapat dipercaya merupakan salah satu faktor yang turut menentukan kinerja pelayanan. Untuk itu diperlukan kemampuan dan kesopanan petugas pelayanan serta ketepatan waktu dan kelancaran teknis pelayanan yang dapat memenuhi ekspektasi para penerima layanan yaitu para wajib pajak yang mengurus keperluan balik nama kendaraan bermotor, STNK dan pembayaran pajak kendaraan bermotor. Dari diskusi masalahmasalah yang terkait dengan faktor assurance yang meliputi kemempuan petugas dalam melayani, kelancaran teknis pelayanan dan ketepatan waktu pelayanan yang tampak dari pelaksanaan tugas pelayanan di Kantor Bersama Samsat Kota Batam, teridentifikasi kinerja pelayanan berikut :

Pertama, kemampuan petugas dalam melayani cukup baik, karena kemampuan petugas dalam melayani yang tampak dari ketepatan waktu pelayanan dan kelancaran teknis pelayanan relatif dianggap telah memenuhi harapan para penerima layanan. Cukup baiknya kemampuan petugas dalam melayani disebabkan petugas pelayanan memang telah memiliki persyaratan kompetensi yang cukup memadai untuk melaksanakan prosedur dan menggunakan sarana pelayanan. Dampaknya, para penerima layanan, yaitu para wajib pajak yang mengurus balik nama kendaraan bermotor, STNK dan 
pembayaran pajak kendaraan bermotor merasa cukup puas terhadap kemampuan petugas dalam melayani. Keadaan ini menunjukkan bahwa penyediaan sarana dan prasarana serta fasilitas pelayanan yang sudah memadai, dapat diimbangi dengan kemampuan petugas dalam melayani. Dengan demikian, bila dinilai indikasi kemampuan petugas dalam melayani dapat dinyatakan bahwa persepsi para wajib pajak terhadap kemampuan petugas dalam melayani mulai sesuai dengan ekspetasi para wajib pajak. Artinya, kepuasan penerima layanan cukup terpenuhi. Dengan pandangan lain, kualitas pelayanan publik yang diselenggarakan oleh Kantor Bersama Samsat Kota Batam menurut indikasi kemampuan petugas dalam melayani pelayanan sudah cukup optimal.

Kedua, kelancaran teknis pelayanan relatif dianggap sudah cukup baik, karena teknis pelayanan yang dilaksanakan oleh petugas-petugas pelayanan pada Kantor Bersama Samsat Kota Batam sudah cukup lancar. Dengan demikian kelancaran teknis pelayanan pada kantor tersebut dapat dianggap cukup optimal. Kelancaran teknis pelayanan yang demikian itu terjadi karena kinerja petugas pelayanan dibantu dengan penerapan teknologi informasi berbasis kompoterisasi. Dampaknya, para penerima layanan, yaitu para wajib pajak yang mengurus balik nama kendaraan bermotor, STNK dan pembayaran pajak kendaraan bermotor merasa cukup puas terhadap kelancaran teknis pelayanan yang diselenggarakan oleh Kantor Bersama Samsat Kota Batam. Keadaan ini menunjukkan bahwa penyediaan sarana dan prasarana serta fasilitas pelayanan yang sudah memadai, dapat diimbangi dengan kelancaran teknis pelayanan yang dianggap sudah cukup baik oleh para penerima layanan. Dengan demikian, bila dinilai dari indikasi kelencaran teknis pelayanan maka dapat dinyatakan bahwa persepsi para wajib pajak terhadap kinerja pelayanan yang diselenggarakan oleh Kantor Bersama Samsat Kota Batam mulai sesuai dengan ekspetasi para wajib pajak. Artinya, kepuasan penerima layanan cukup terpenuhi. Dengan pandangan lain, kualitas pelayanan publik yang diselenggarakan oleh Kantor Bersama Samsat Kota Batam menurut indikasi kelancaran teknis pelayanan sudah cukup optimal.

Ketiga, ketepatan waktu pelayanan relatif dianggap sudah baik, karena antara waktu pelayanan yang dijanjikan oleh Kantor Bersama Samsat Kota Batam dengan waktu pelayanan yang ditepati tidak menunjukkan selisih waktu yang lama. Dengan demikian ketepatan waktu pelayanan pada kantor tersebut dapat dianggap cukup optimal. Ketepatan waktu pelayanan yang demikian itu terjadi karena kinerja petugas pelayanan dibantu dengan penerapan teknologi informasi berbasis kompoterisasi. Dampaknya, para penerima layanan, yaitu para wajib pajak yang mengurus balik nama kendaraan bermotor, STNK dan pembayaran pajak kendaraan bermotor merasa cukup puas terhadap ketepatan waktu pelayanan yang diselenggarakan oleh Kantor Bersama Samsat Kota Batam. Keadaan ini menunjukkan bahwa penyediaan sarana dan prasarana serta fasilitas pelayanan yang sudah memadai, dapat diimbangi dengan ketepat waktu pelayanan yang sudah dianggap relatif cukup baik oleh para penerima layanan. Dengan demikian, bila dinilai indikasi ketepatan waktu pelayanan maka dapat dinyatakan bahwa 
persepsi para wajib pajak terhadap kinerja pelayanan yang diselenggarakan oleh Kantor Bersama Samsat Kota Batam mulai sesuai dengan ekspetasi para wajib pajak. Artinya, kepuasan penerima layanan cukup terpenuhi. Dengan pandangan lain, kualitas pelayanan publik yang diselenggarakan oleh Kantor Bersama Samsat Kota Batam menurut indikasi ketepatan waktu pelayanan sudah cukup optimal.

\section{Analisis Faktor Emphaty}

Jika kita berbicara tentang kesiapan petugas pelayanan, maka persoalannya tentu tidak terbatas hanya pada pengertian kesiapan fisik saja. Kesiapan petugas pelayanan dalam aspek-aspek lainnya juga diperlukan. Misalnya, kesiapan mental petugas pelayanan dalam menghadapi karakteristik penerima layanan yang berbeda-beda. Dari diskusi masalah-masalah yang terkait dengan faktor emphaty yang meliputi kesiapan petugas pelayanan, perhatian petugas pelayanan dan kepedulian petugas pelayanan yang tampak dari pelaksanaan tugas-tugas pelayanan di Kantor Bersama Samsat Kota Batam, teridentifikasi kinerja pelayanan sebagai berikut :

Pertama, kesiapan petugas pelayanan cukup baik, karena ketepatan waktu pelayanan dan kelancaran teknis pelayanan relatif dianggap telah cukup memenuhi harapan para penerima layanan. Cukup baiknya kesiapan petugas pelayanan karena waktu kerja dan pola kerja para petugas pelayanan memang sudah diatur sedemikian rupa sehingga setiap petugas memahami fungsi jabatan atau pekerjannya masing-masing. Dampaknya, para penerima layanan, yaitu para wajib pajak yang mengurus balik nama kendaraan bermotor, STNK dan pembayaran pajak kendaraan bermotor merasa cukup puas terhadap kesiapan petugas pelayanan. Keadaan ini menunjukkan bahwa penyediaan sarana dan prasarana serta fasilitas pelayanan yang sudah memadai, dapat diimbangi dengan kesiapan petugas pelayanan. Dengan demikian, bila dinilai indikasi kesiapan petugas pelayanan maka dapat dinyatakan bahwa persepsi para wajib pajak terhadap kesiapan petugas pelayanan mulai sesuai dengan ekspetasi para wajib pajak. Artinya, kepuasan penerima layanan cukup terpenuhi. Dengan pandangan lain, kualitas pelayanan publik yang diselenggarakan oleh Kantor Bersama Samsat Kota Batam menurut indikasi kesiapan petugas pelayanan sudah cukup optimal.

Kedua, perhatian petugas pelayanan cukup baik, karena perhatian pada ketepatan waktu pelayanan dan kelancaran teknis pelayanan relatif dianggap telah cukup memenuhi harapan para penerima layanan. Cukup baiknya perhatian petugas pelayanan karena pemahaman fungsi jabatan atau pekerjaan pada masing-masing petugas sudah memang sudah terpola sedemikian rupa sehingga setiap petugas memahami apa saja yang perlu diperhatikan menurut fungsi jabatan atau pekerjannya masing-masing. Dampaknya, para penerima layanan, yaitu para wajib pajak yang mengurus balik nama kendaraan bermotor, STNK dan pembayaran pajak kendaraan bermotor merasa cukup puas terhadap perhatian petugas pelayanan. Keadaan ini menunjukkan bahwa penyediaan sarana dan prasarana serta fasilitas pelayanan yang sudah memadai, dapat diimbangi dengan 
perhatian petugas pelayanan. Dengan demikian, bila dinilai indikasi perhatian petugas pelayanan maka dapat dinyatakan bahwa persepsi para wajib pajak terhadap perhatian petugas pelayanan mulai sesuai dengan ekspetasi para wajib pajak. Artinya, kepuasan penerima layanan cukup terpenuhi. Dengan pandangan lain, kualitas pelayanan publik yang diselenggarakan oleh Kantor Bersama Samsat Kota Batam menurut indikasi perhatian petugas pelayanan sudah cukup optimal.

Ketiga, kepedulian petugas pelayanan cukup baik, karena kepedulian petugas pelayanan pada keluhan penerima layanan diimbangi dengan ketepatan waktu pelayanan dan kelancaran teknis pelayanan yang dianggap relatif cukup memenuhi harapan para penerima layanan. Cukup baiknya kepedulian petugas pelayanan pada keluhan penerima layanan didasarkan pada ruang lingkup pekerjaan masingmasing petugas yang memang sudah terpola sedemikian rupa sehingga setiap petugas memahami apa saja yang perlu dipedulikan menurut fungsi jabatan atau pekerjannya. Dampaknya, para penerima layanan, yaitu para wajib pajak yang mengurus balik nama kendaraan bermotor, STNK dan pembayaran pajak kendaraan bermotor merasa cukup puas terhadap kepdulian petugas pelayanan. Keadaan ini menunjukkan bahwa penyediaan sarana dan prasarana serta fasilitas pelayanan yang sudah memadai, dapat diimbangi dengan kepedulian petugas pelayanan sesuai dengan fungsi jabatan atau pekerjanannya. Dengan demikian, bila dinilai indikasi kepedulian petugas pelayanan maka dapat dinyatakan bahwa persepsi para wajib pajak terhadap kepedulian petugas pelayanan mulai sesuai dengan ekspetasi para wajib pajak. Artinya, kepuasan penerima layanan cukup terpenuhi. Dengan pandangan lain, kualitas pelayanan publik yang diselenggarakan oleh Kantor Bersama Samsat Kota Batam menurut indikasi kepedulian petugas pelayanan pada keluhan penerima layanan sudah cukup optimal.

\section{Analisis Faktor Reliability}

Pada akhirnya, setelah sarana dan prasarana serta fasilitas pelayanan tersedia cukup lengkap, selanjutnya yang menjadi persoalan adalah bagaimana keandalan individu petugas pelayanan, keandalan unit pelayanan dan keandalan organisasi Kantor Bersama Samsat Kota Batam. Dari diskusi masalah-masalah yang terkait dengan faktor reliability yang meliputi keandalan individu petugas pelayanan, keandalan unit-unit pelayanan dan keandalan organisasi Kantor Bersama Samsat Kota Batam yang tampak dari pelaksanaan kebijakan dan kegiatan pelayanan publik di bidang perpajakan, teridentifikasi kinerja pelayanan sebagai berikut :

Pertama, keandalan individu petugas pelayanan cukup baik, karena keandalan tersebut tercarmin pada ketepatan waktu pelayanan dan kelancaran teknis pelayanan yang relatif dianggap sudah cukup memenuhi harapan para penerima layanan. Cukup baiknya keandalan individu petugas pelayanan karena masingmasing petugas pelayanan memang sudah memahami dan terbiasa melaksanakan fungsi pekerjaannya. Dampaknya, para penerima layanan, yaitu para wajib pajak yang mengurus balik nama kendaraan bermotor, STNK dan pembayaran pajak 
kendaraan bermotor merasa cukup puas terhadap keandalan individu petugas pelayanan. Keadaan ini menunjukkan bahwa penyediaan sarana dan prasarana serta fasilitas pelayanan yang sudah memadai, dapat diimbangi dengan keandalan individu petugas pelayanan. Dengan demikian, bila dinilai indikasi keandalan individu petugas pelayanan maka dapat dinyatakan bahwa persepsi para wajib pajak terhadap keandalan invidu petugas pelayanan mulai sesuai dengan ekspetasi para wajib pajak. Artinya, kepuasan penerima layanan cukup terpenuhi. Dengan pandangan lain, kualitas pelayanan publik yang diselenggarakan oleh Kantor Bersama Samsat Kota Batam menurut indikasi keandalan individu petugas pelayanan sudah cukup optimal.

Kedua, keandalan unit-unit pelayanan cukup baik, karena keandalan tersebut tercarmin pada ketepatan waktu pelayanan dan kelancaran teknis pelayanan yang relatif dianggap sudah cukup memenuhi harapan para penerima layanan. Cukup baiknya keandalan unit-uit pelayanan karena kinerja masing-masing unit pelayanan telah terkoordinasi dalam melaksanakan tugas dan fungsi unit pelayanan. Dampaknya, para penerima layanan, yaitu para wajib pajak yang mengurus balik nama kendaraan bermotor, STNK dan pembayaran pajak kendaraan bermotor merasa cukup puas terhadap keandalan unit-unit pelayanan pada Kantor Bersama Samsat Kota Batam. Keadaan ini menunjukkan bahwa penyediaan sarana dan prasarana serta fasilitas pelayanan yang sudah memadai, dapat diimbangi dengan keandalan individu petugas pelayanan. Dengan demikian, bila dinilai indikasi keandalan unit-unit pelayanan maka dapat dinyatakan bahwa persepsi para wajib pajak terhadap keandalan unit-unit pelayanan mulai sesuai dengan ekspetasi para wajib pajak. Artinya, kepuasan penerima layanan cukup terpenuhi. Dengan pandangan lain, kualitas pelayanan publik yang diselenggarakan oleh Kantor Bersama Samsat Kota Batam menurut indikasi keandalan unit-unit pelayanan sudah cukup optimal.

Ketiga, keandalan organisasi Kantor Bersama Samsat Kota Batam cukup baik, karena keandalan tersebut tercarmin juga pada ketepatan waktu pelayanan dan kelancaran teknis pelayanan yang relatif dianggap sudah cukup memenuhi harapan para penerima layanan. Cukup baiknya keandalan organisasi tersebut karena didasarkan pada struktur kewenangan serta uraian tugas dan fungsi yang jelas dan terkoordinasi sebagai satu kesatuan penyelenggara pelayanan publik di bidang perpajakan. Dampaknya, para penerima layanan, yaitu para wajib pajak yang mengurus balik nama kendaraan bermotor, STNK dan pembayaran pajak kendaraan bermotor merasa cukup puas terhadap keandalan organisasi Kantor Bersama Samsat Kota Batam. Keadaan ini menunjukkan bahwa penyediaan sarana dan prasarana serta fasilitas pelayanan yang sudah memadai, dapat diimbangi dengan keandalan organisasi dalam menyelenggarakan suatu sistem pelayanan publik. Dengan demikian, bila dinilai indikasi keandalan organisasi maka dapat dinyatakan bahwa persepsi para wajib pajak terhadap keandalan organisasi mulai sesuai dengan ekspetasi para wajib pajak. Artinya, kepuasan penerima layanan cukup terpenuhi. Dengan pandangan lain, kualitas pelayanan publik yang 
diselenggarakan oleh Kantor Bersama Samsat Kota Batam menurut indikasi keandalan organisasi sudah cukup optimal.

Dari analisis kelima faktor yang menentukan kualitas pelayanan pemungutan pajak kendaraan bermotor pada Kantor Bersama Samsat Kota Batam diperoleh rangkuman hasil penelitian sebagai berikut :

Pertama, dari kelima faktor servequal yang dijadikan landasan teoritik penyusunan konsep penelitian diketahui bahwa hanya faktor responsiveness saja yang mencerminkan kelemahan kinerja pelayanan yang diselenggarakan oleh Kantor Bersama Samsat Kota Batam. Kelemahan pada faktor responsiveness terungkap dari respon petugas pelayanan pada keluhan penerima layanan; respon petugas pelayanan pada kritikan penerima layanan; dan respon petugas pelayanan pada kesulitan penerima layanan, yaitu para wajib pajak yang mengurus balik nama kendaraan bermotor, STNK dan pembayaran pajak kendaraan bermotor.

Kedua, hasil penelitian yang demikian itu dapat juga dimaknai sebagai suatu kajian yang lebih mendalam terhadap kelemahan kinerja pelayanan pada Kantor Bersama Samsat Kota Batam yang ditunjukkan oleh hasil survei yang dilaksanakan oleh Kantor Pelayanan Pendapat Daerah Kota Batam dan Kantor Bersama Samsat Kota Batam. Pendalaman ini merujuk pada hasil survei yang menunjukkan adanya 4 unsur pelayanan yang mendapat skor dibawah 3 dengan krtiteria "Baik", yaitu (1) prosedur pelayanan, (2) keadilan mendapatkan pelayanan, (3) kesopanan dan keramahan petugas, dan (4) kepastian jadwal pelayanan. Meskipun keempat unsur pelayanan tersebut dalam hasil survei dinyatakan "Baik", namun karena survei tersebut bersifat kuantatif yang hanya menonjolkan pertanyaan tertutup dengan pilihan jawaban yang sangat terbatas, maka hasil penelitian yang dilakukan oleh Kantor Pelayanan Pendapat Daerah Kota Batam dan Kantor Bersama Samsat Kota Batam kurang merepresentasikan persepsi dan ekspetasi para pnerima layanan yang terdiri atas sejumlah kalangan yang mesing-masing kalangan memiliki karakteristik permasalahan yang berbeda.

Ketiga, keempat unsur pelayanan yang menunjukkan kelemahan kinerja pelayanan pada Kantor Bersama Samsat Kota Batam meliputi (1) prosedur pelayanan, (2) keadilan mendapatkan pelayanan, (3) kesopanan dan keramahan petugas, dan (4) kepastian jadwal pelayanan, merupakan cerminan dari kelemahan kinerja petugas pelayanan yang meliputi (1) respon petugas pelayanan pada keluhan penerima layanan, (2) respon petugas pelayanan pada kritikan penerima layanan, dan (3) respon petugas pelayanan pada kesulitan penerima layanan.

Keempat, dengan demikian diperoleh temuan empirik yang menunjukkan adanya kelemahan unsur pelayanan yang menyebabkan belum optimalnya kualitas pelayanan pemungutan pajak kendaraan bermotor pada Kantor Bersama Samsat Kota Batam, yaitu kelemahan kinerja petugas pelayanan menurut analisis faktor responsiveness. 


\section{SIMPULAN}

Dari pembahasan 5 faktor yang merefleksikan kualitas pelayanan pemungutan pajak kendaraan bermotor pada Kantor Bersama Samsat Kota Batam diperoleh kesimpulan bahwa yang menyangkut faktor tangible, yaitu penyediaan loket-loket sudah cukup memadai, namun penyediaan loket menjadi kurang memadai ketika jumlah kehadiran para wajib pajak melebihi kapasitas loket tersebut. Penyediaan ruang tunggu cukup memadai, namun penyediaan ruang tunggu menjadi kurang memadai ketika jumlah kehadiran para wajib pajak melebihi kapasitas tempat duduk yang tersedia di ruang tunggu. Jumlah petugas pelayanan cukup memadai, namun kompetensi petugas pelayanan kurang memadai. Menyangkut faktor responsiveness, yaitu respon petugas pelayanan pada keluhan penerima layanan dianggap kurang baik karena itu belum memenuhi harapan para penerima layanan. Respon petugas pelayanan pada kritikan penerima layanan dianggap kurang baik karena itu belum memenuhi harapan para penerima layanan. Respon petugas pelayanan pada kesulitan penerima layanan dianggap kurang baik karena itu belum memenuhi harapan para penerima layanan. Menyangkut faktor assurance, yaitu kemampuan petugas dalam melayani dianggap cukup baik karena itu cukup memenuhi harapan penerima layanan. Kelancaran teknis pelayanan dianggap cukup baik karena itu cukup memenuhi harapan penerima layanan. Ketepatan waktu pelayanan dianggap cukup baik karena itu cukup memenuhi harapan penerima layanan. Menyangkut faktor emphaty, yaitu kesiapan petugas pelayanan dianggap cukup baik karena itu cukup memenuhi harapan penerima layanan. Perhatian petugas pelayanan dianggap cukup baik karena itu cukup memenuhi harapan penerima layanan. Kepedulian petugas pelayanan dianggap cukup baik karena itu cukup memenuhi harapan penerima layanan. Menyangkut faktor reliability, yaitu keandalan individu petugas pelayanan dianggap cukup baik karena itu cukup memenuhi harapan penerima layanan. Keandalan unit-unit pelayanan dianggap cukup baik karena itu cukup memenuhi harapan penerima layanan. Keandalan organisasi Kantor Bersama Samsat Kota Batan dianggap cukup baik karena itu cukup memenuhi harapan penerima layanan. Dengan kondisi pelayanan yang demikian itu maka persepsi para penerima layanan pemungutan pajak kendaraan bermotor dapat dimaknai kurang terpuaskan, karena belum seluruh elemen kualitas pelayanan dapat memenuhi harapan penerima layanan.

Konsep baru yang bisa diangkat dari kesimpulan adalah respon petugas pelayanan dalam meningkatkan kualitas pelayanan publik yang menyangkut kepekaan dan daya tanggap dalam menyikapi, mengatasi dan mengantisipasi keluhan, kritikan dan kesulitan para penerima layanan yang timbul sebagai akibat lemahnya kinerja pelayanan. 
Dengan kesimpulan yang diperoleh dari pembahasan hasil penelitian tersebut, maka saran yang perlu disampaikan untuk meningkatkan kualitas pelayanan publik di bidang perpajakan adalah berikut :

Pertama, perlu ditingkatkan kepekaan dan daya tanggap (responsiveness) para petugas pelayanan dalam menyelenggarakan fungsi pelayanan publik, agar kualitas pelayanan publik yang diselenggarakan oleh unit-unit kerja birokrasi pemerintahan dapat memenuhi harapan para penerima layanan yang semakin kritis terhadap kinerja pelayanan publik yang diselenggarakan oleh birokrasi. Peningkatan kepekaan dan daya tanggap petugas pelayanan tersebut dapat diaktualisasikan dengan cakupan tiga dimensi kepekaan dan daya tanggap yang efektif untuk meningkatkan kualitas pelayanan, yakni : (1) Dimensi respon petugas pelayanan pada keluhan penerima layanan; (2) Dimensi respon petugas pelayanan pada kritikan penerima layanan; dan (3) Dimensi respon petugas pelayanan pada kesulitan penerima layanan.

Kedua, secara umum disarankan kepada Pemda Provinsi Kepulauan Riau agar dikeluarkan kebijakan khusus tentang pembinaan sumber daya aparatur untuk meningkatkan profesionalitas respon petugas pelayanan pada kesulitan penerima layanan, dan mengoptimalkan kepekaan dan daya tanggap aparatur penyelenggara pelayanan publik, terutama pelayanan publik di bidang perpajakan yang diperlukan untuk meningkatkan Pendapatan Asli Daerah. Pembinaan sumber daya aparatur yang dimaksud disertai juga dengan pemberian reward atau terhadap pejabat/petugas pelayanan publik yang terbukti mampu meraih prestasi kerja yang optimal dan atau tidak dapat melaksanakan tugas dan tanggungjawabnya secara optimal. Secara khusus, disarankan kepada pimpinan Kantor Samsat Kota Batam agar mengadakan kegiatan Diklat Fungsional bagi pegawai-pegawai yang bertugas di front office atau melaksanakan fungsi teknis pelayanan.

\section{DAFTAR PUSTAKA}

Zeithaml, Valarie A., Parasuraman,A and.Berry, Leonard L. 1990. Delivering Quality Service: Balancing Customer perceptions and Expectations. The Free Press: Adivision of Macmillan,Inc.

Ratminto, dan Atik Septi Winarsih, 2005, Manajemen Pelayanan, Jakarta: Pustaka Pelajar.

Sinambela, Poltak, Lijan, 2007, Reformasi Pelayanan Publik, Jakarta : PT. Bumi Aksara.

Dwiyanto, Agus, 2005, Mewujudkan Good Governance Melalui Pelayanan Publik, Jakarta: Gadjah Mada University Press. 